QIJIS: Qudus International Journal of Islamic Studies Volume 4, Issue 2, August 2016

\title{
ISLAMIC EDUCATION OF CHILDREN WITH PARENTS AS INDONESIAN MIGRANT WORKERS (Case Study in Karangwotan Village, Pati, Central Java)
}

\author{
Suciati \\ STAIN Kudus, Central Java, Indonesia \\ suci.stainkudus@gmail.com
}

\begin{abstract}
Many parents who decided to work abroad as International migrant workers. They work for financial fulfilment. On the other hand, their children do not get more attention from them because the children are usually left by father/mother or both of them to work abroad and the children are at home just with their mothers or grandparents. This qualitative research was conducted in Karangwotan village, Pati, Central Java. The data showed three result: (1) problems faced by the children with parents as immigrant in getting Islamic education are that they do not have the real model in the family and there was no father/mother or both of them who teach and educate in the family; (2) there is just little parents' influence to children's islamic education. It is just such kind of order, suggestion and advice; and (3) for getting the islamic education, the children with parents as immigrant workers join several islamic programs. They are Taman Pendidikan Qur'an (TPQ) or Program of Qur'an Education, Madrasah Ibtidaiyyah or Islamic Elementary School, and the islamic courses.
\end{abstract}


Keywords: Islamic Education, Children, Parents as Indonesian Migrant Workers

\section{A. Introduction}

Education is the fundamental thing for people. For developing their Islamic knowledge, they should try to get the islamic education. As moslems, they cannot be separated from education. Without education or knowledge, they will not be able to understand Islam fully. Someone will not have full realization of obligations and indeed potency to observe Islam if he does not have strong foundation in Islamic knowledge. The concept of knowledge in Islam involves both holistic and practical one. Education in Islam can promote human dignity and enhance the human personality. Generally, Islamic literacy is defined as the ability to read and understand the Qur'an, understand the basic Islamic principles and practice it in the daily life. So, in the beginning of studying Islam, someone needs the guidance from the other people. Bajunid (2011:159) argued that, as made explicit in several Qur'anic injunctions, the status of people whose knowledge and those who do not have it cannot possibly be the same.

If someone, especially a child want to study about Islam without any guidance, he will find the difficulties. For that reason, the role of parents is needed and very important to support his education. The importance of the family role for children's education is the main key for the child's success, especially in Islamic education. The family is an environment that consists of those closest people to the child. There are a lot of time and opportunity for a child to meet and interact with his family. The encounter of these interactions is certainly a very large effect on a child's behavior. Family and education are two terms that cannot be separated because there is a family, there is education. The family is the first environment which has the greatest role for child's development. A child interacts with his family (mother, father, sister, brother, etc.) in their daily lives. So it can be said that the 
family has a great influence on a child. The children who do not get the attention from parents well tend to have different morals with the children who get full attention from their parents. In general, children are taken care of grandparents tend to be pampered.

For implementing moral education, all society elements must get involved actively in education process. Implementing good moral for children or students is not just duty of teachers at school, but it is also parents' duty and responsibility. Parents have direct duty in educating the children. They become the main and first educator for children in informal education area; that is home or family. Nevertheless, there will be some problems if a mother or father is not at home and work in another country. This condition also happens in Karangwotan village, Pati, Central Java. So many parents work abroad and leave their children at home, in Indonesia. For that reason, the writer conducted research entitle 'Islamic Education of Children with Parents as Migrant Workers'. It was study in Karangwotan Village, Pati, Central Java. Hopefully, by observing and analyzing the children, the writer would know the condition and get the problem solving.

Based on the background above, the writer formulated some statements of the problem. They were:

1. What problems were faced by the children with parents as immigrant in getting islamic education?

2. How was the parents' influence to children's islamic education?

3. How did children with parents as immigrant workers get islamic education?

Based on the statements of the problem above, the reseracher wanted to find the problems which were faced by the children with parents as immigrant in getting islamic education, the parents' influence to children's islamic education, and the way of children with parents as immigrant workers to get islamic education. 


\section{B. Review of Previous Studies}

There are some previous studies that have been conducted with focus on Islamic Education. Khoirudin (2015) conducted the research entitled 'the Influence of Parents (Migrant Workers) to the Moral of Students Class XI SMA Negeri Jumapolo Kabupaten Karanganyar Tahun Pelajaran 2014/2015'. In this research, he tried to find the moral condition of students which were left by their parents to work abroad and the influence of parents who work abroad to the students' moral to the others.

From the first previous study, there is similarity and differences. The similarity is that both this research and that research discuss abou the influence of parents who become migrant workers. Meanwhile, there are some differences. The first, it focused on the parents influence and moral of the students, but this research focused on the islamic education of children. The second is that research was conducted at school. And, this research was conducted in Karangwotan, Pucakwangi, Pati, Central Java.

The next one is research conducted by Salleh [2013:1112) which stated that Islamic education makes many Muslims interested to deal with and endeavour its realization. There are some accomplishment of the Islamic education aims. However, those aims should be balanced by continuous exercises. Certain kind of strategy he tried in his research. He also suggested three aspects that should be given tobe consideration in improving the strategy. The first is the adoption of an Islamic management method in the Islamic educational institutions; the second is the emphasis on the teaching-learning method, namely 'heart-to-heart' method; and the third is the creation of one's own innovation, standard and playing arena. Islamic education can be a great endeavor to create harmonious life for all people. The second previous study is so clear that it is so different with this research because it discussed the islamic education in broader context.

Then, Prihatini (2013) also conducted the research about children with parents as migrant workers entitled "Psychosocial Problem of Teenagers with Parents as Migrant Workers". In her 
reserach, she concluded that teenagers with parents as migrant workers tend to be susceptible to have psychosocial problems related to the usage of alcohol, smoking, beer, and other problems related to social relation like playing truant, fighting, and gambling. Meanwhile, reserach conducted by Pokro (2002) with title “Optimizing the Parents Role to Develop the Students' Moral in Madrasah Aliyah Negeri Kupang in the Academic Year 2002/2003" got the result that parents' role as educator and controller of students' moral was not done optimally because the education background and the lack of parents' knowledge about the moral for educating the students.

The last study discussed about the children with parents as migrant workers too, but it focused on teenagers, not children. Moreover, it discussed the psychosocial problems of teenagers. On the other hand, this research discussed about the islamic education of children.

From the review of previous studies above, it is so clear that they have differences with the qualitative research which was conducted by the researcher.

\section{Islamic Education}

Many muslim countries adopt model about islam which has been practiced by Japan. That model is 'Modernization without Westernization. In this model, education systems are 'nationalised'. First, most of the Middle East, North Africa, and Pakistan, determine the curriculum and the system structure. Second, the national language was introduced. And thirdly, they include Islamic matters in the curriculum of state education. In some countries, like in Egypt, Indonesia, and Pakistan, the state have the parallel system which emerges during the colonial period when the secular school network expanded along with the Islamic schools. In countries with a less influential Muslim tradition, like countries in Sub-Saharan Africa and some Asian countries, they maintain the secular education. In all of such countries, the state does not arrange the Islamic education and it is established outside 
of state scope (Daun, Arjmand and Walford, 2004:9-10).

In the Western countries, like in Europe, at least there are three countries categories that are related to the Islamic education. The first are the countries which have unitary and national system (national curriculum and secular education). The second are the countries that choose neither to control nor support Muslim education as an alternative system of education. And the last are the countries that choose a multi-cultural framework to try to accommodate immigrant and minority cultures, hence choosing for a "compromise" to establish supplementary education (based on a national curriculum) and economically subsidizing such arrangement (Daun and Walford 2004:1).

Islam is not just known as religion. It cannot be known and understood by narrow knowledge. It is not just aboutobligation, rites, rituals, rules and doctrines. Islam is also not just about spirituality but it also includes each aspect of human life. Islamic education is beneficial so it can be used to empower every individual believer with the appropriate knowledge and it can be a means for finding the right answers to life. For that reason, Muslims in the world must learn about the fundamental Islam principles. They are worldview, laws, practices, history, languages, the Qur'an and the Sunnah. All of those Islam foundations must be related to the broader spectrum of knowledge which covers worldly matters (Bajunid, 2011:160).

\section{Children Characters}

Character includes attitudes, behaviors, motivations, and skills. It is more than simply avoiding involvement in socially undesirable behaviors. Character includes attitudes like the willingness to do the best, being concerned to the welfare, having intellectual capacity like crithical thinking and moral reasoning. Then, the examples of behaviors are like being honest, responsible, and standing up for moral principles. For the skill, it involves interpersonal and emotional skills so they can support the inviduals to interact effectively with the other people in various 
circumstances; and the commitment to contribute to the community and society. The point is that character is the someone's realization for having good or positive development, like intellectual, social, emotional and ethical. It means that all of those points chould be balanced. For being person whose good character, someone should be able to do or practice the best one. To be a person of good character is to be the best person that one can be. (Berkowitz in Hansen, Giles, and Fearnow-Kenney, 2000:37-45).

Almerico (2014:4) stated that a panel of 20 educators who master character education recommended some characters which is so important to be included in character development. They are (1) caring, compassion, kindness, and empathy, (2) citizenship, (3) courage, (4) fairness, (5) honesty and trustworthiness, (6) integrity, (7) leadership, (8) perseverance in establishing and attaining goals, (9) respect, (10) responsibility, and (11) team work and cooperation.

\section{E. Indonesian Migrant Workers}

Based on data from Pusat Penelitian Pengembangan dan Informasi (PUSLITFO BNP2TKI, 2016) or center of reserach, development and information related to Indonesian Migrant Workers, the number of Indonesian migrant workers can be described in the table below:

\begin{tabular}{|c|l|c|}
\hline No. & Year & Total of Indonesian Migrant Workers \\
\hline & 2011 & 586.802 \\
\hline & 2012 & 494.609 \\
\hline & 2013 & 512.168 \\
\hline & 2014 & 429.872 \\
\hline & 2015 & 275.736 \\
\hline & January to May & 120.965 \\
\hline & 2016 & 97.349 \\
\hline & January to May & \multicolumn{2}{|c|}{} \\
\hline
\end{tabular}

It desribes that the number of the Indonesian migrant workers are so big. For January to May 2016, the newest data from PUSLITFO BNP2TKI (2016) also shows that they are from various 
provinces in Indonesia. The data of the placement of Indonesian migrant workers in other countries are like below.

\begin{tabular}{|c|l|l|l|}
\hline No. & \multicolumn{1}{|c|}{ Provinces } & \multicolumn{1}{|c|}{$\mathbf{2 0 1 5}$} & \multicolumn{1}{c|}{$\mathbf{2 0 1 6}$} \\
January-May & January - May \\
\hline 1 & West Java & 28.690 & 21.545 \\
\hline 2 & Central Java & 25.319 & 18.887 \\
\hline 3 & West Nusa Tenggara & 23.004 & 18.115 \\
\hline 4 & East Java & 19.965 & 17.358 \\
\hline 5 & Lampung & 6.880 & 6.793 \\
\hline 6 & North Sumatera & 3.911 & 6.134 \\
\hline 7 & Bali & 2.605 & 1.276 \\
\hline 8 & Banten & 2.022 & 1.262 \\
\hline 9 & East Nusa Tenggara & 1.580 & 1.078 \\
\hline 10 & West Kalimantan & 806 & 849 \\
\hline 11 & South Sulawesi & 1.500 & 391 \\
\hline 12 & Yogyakarta & 821 & 583 \\
\hline 13 & South Sumatera & 582 & 563 \\
\hline 14 & Jakarta & 661 & 367 \\
\hline 15 & Kepri & 337 & 379 \\
\hline 16 & West Sumatera & 305 & 360 \\
\hline 17 & Aceh & 277 & 356 \\
\hline 18 & Riau & 261 & 272 \\
\hline 19 & Central Sulawesi & 319 & 156 \\
\hline 20 & Jambi & 175 & 205 \\
\hline 21 & South Kalimantan & 165 & 126 \\
\hline 22 & North Sulawesi & 250 & 60 \\
\hline 23 & Bengkulu & 138 & 120 \\
\hline 24 & East Kalimantan & 101 & 35 \\
\hline 25 & West Sulawesi & 87 & 26 \\
\hline 26 & South East Sulawesi & 81 & 21 \\
\hline 27 & North Maluku & 54 & 5 \\
\hline 28 & Maluku & 42 & 5 \\
\hline 29 & Central Kalimantan & 13 & 7 \\
\hline 30 & Bangka Belitung & 8 & 8 \\
\hline 31 & Papua & 2 & 3 \\
\hline 32 & West Papua & 2 & 3 \\
\hline 33 & Gorontalo & 2 & 97.349 \\
\hline Total & & 120.965 & \\
\hline & & & \\
\hline
\end{tabular}

Kang (2016) stated that the study surveyed over 1,000 domestic workers in Hongkong, almost all either from the Philippines (51\%) or Indonesia (46\%). Moreover, they are placed 
in so many countries. The data from PUSLITFO BNP2TKI (2016), they are spread in 146 countries. The table below shows some countries that are categorized as place that the workers are interested in.

\begin{tabular}{|c|l|l|l|}
\hline No. & \multicolumn{1}{|c|}{ Countries } & \multicolumn{1}{|c|}{$\begin{array}{c}\mathbf{2 0 1 5} \\
\text { January-May }\end{array}$} & $\begin{array}{c}2016 \\
\text { January-May }\end{array}$ \\
\hline 1 & Malaysia & 39.581 & 38.115 \\
\hline 2 & Taiwan & 31.894 & 31.889 \\
\hline 3 & Saudi Arabia & 8.736 & 6.743 \\
\hline 4 & Singapore & 7.649 & 6.313 \\
\hline 5 & Hong Kong & 6.966 & 6.033 \\
\hline 6 & Brunei Darussalam & 4.401 & 3.545 \\
\hline 7 & United Arab Emirates & 2.511 & 1.236 \\
\hline 8 & Oman & 6.154 & 292 \\
\hline 9 & South Korea & 4.521 & 1.067 \\
\hline 10 & Qatar & 1.487 & 443 \\
\hline 11 & Bahrain & 2.150 & 42 \\
\hline 12 & Italy & 697 & 220 \\
\hline 13 & Turkey & 722 & 354 \\
\hline 14 & United States & 776 & 114 \\
\hline 15 & Japan & 112 & 18 \\
\hline 16 & New Zealand & 130 & 90 \\
\hline 17 & Kuwait & 153 & 124 \\
\hline 18 & Spain & 65 & 37 \\
\hline 19 & Gabon & 146 & 10 \\
\hline 20 & Fiji ISLANDS & 210 & 1 \\
\hline 21 & Maldives & 55 & 71 \\
\hline 22 & Brazil & 87 & 99 \\
\hline 23 & Germany & 111 & 23 \\
\hline 24 & Zambia & 94 & 54 \\
\hline 25 & Aljazair & 0 & 63 \\
\hline 26 & Others & 1.557 & 353 \\
\hline TOTAL & & 120.965 & 97.349 \\
\hline & & & \\
\hline
\end{tabular}

It describes that there are so many people from Indonesia who work a broad wherea s it is just data along six months in 2016. And, the data of workers whether they are married or not yet is below:

\begin{tabular}{|l|l|c|c|}
\hline No & Marital Status & $\begin{array}{c}\mathbf{2 0 1 6} \\
\text { (January-May) }\end{array}$ & $\begin{array}{c}\text { Percentage } \\
\text { (\%) }\end{array}$ \\
\hline & Married & 50.541 & 52 \\
\hline
\end{tabular}




\begin{tabular}{|l|l|c|c|}
\hline & Unmarried & 40.058 & 41 \\
\hline & Widower/widow & 6.750 & 7 \\
\hline Total & 97.349 & 100 \\
\hline
\end{tabular}

From the data above, it shows that married people or parents dominate the number of Indonesian migrant workers in other countries. Indirectly, it influences the children condition because most of them work abroad without asking the children to join there.

\section{F. Research Method}

This reserach was field study with qualitative approach. It is like what Denzin and Lincoln (2005:3) described that qualitative research involves "... an interpretive naturalistic approach to the world. This means that qualitative researchers study things in their natural settings, attempting to make sense of or interpret phenomena in terms of the meanings people bring to them." From that definition, it can be known that phenomenon that was researched here was the islamic education of the children with parents as the migrant workers. The were the problems which were faced by the children with parents as immigrant in getting islamic education, the parents' influence to children's islamic education, and the way of children with parents as immigrant workers to get islamic education. This research used qualitative approach because the researcher wanted to get the information in detail about those three purposes.

In applying qualitative research method, the reseracher should put on the natural setting and the research participants' points of views. In qualitative research, self-reflection about someone's attitude, position and role in society is vital. It is strengthened by the statements of Denzin and Lincoln (2005:21): "Behind all research stands the biography of the gendered researcher, who speaks from a particular class, racial, cultural and ethnic community perspective“. 
From the explanation above, it can be understood that for getting the result, this reserach used some methods. Moreover, the methods used were:

a. Observation

In this method, the researcher used non participant observation. It means that the researcher did not involve the participants to find the data. The researcher just observed the children's attitude and behavior.

b. Interview

Interview means finding the information or sharing idea through asking and answering so the meaning or points can be constructed to get the supporting data about certain topic. In this research, the interview was done to get the information from the children with parents as migrant workers and also from the family who were responsible or took care of them, for example their grandfathers or grandmothers.

c. Documentation

Documentation was the data of some variables, like note, script, agenda, and many others. This documentation used by the researcher to strengthen the result of observation and interview.

This research was conducted in Karangwotan village, Pucakwangi district, Pati, Central Java. For taking the sample, the researcher used purposive sampling technique because in this village, there was $83 \%$ of the children (kindergarten and elementary school-age) were left by parents, especially their fathers to work as Indonesian migrant workers abroad. For that reason, the researcher wanted to know the condition of the children and their islamic education system.

\section{G. Findings and Discussion}

The data obtained for this research were taken from observation, interview and documentation. The events that occured in a social situation was the main concern of this qualitative 
research. Researchers went to the location to understand and study the situation. Studies conducted at the time of the interaction took place on the field. Researchers observed, took notes, asked, found source closely associated with the events that occurred at that time. All of those data were processed qualitatively. The results obtained at that time were arranged at the same time. What was observed basically could not be separated from the environmental context in which the behavior took place. The results of data analysis were presented in the form of a narrative description. The nature of the exposure of data in general was to answer the questions of why and how a phenomenon occurs.

Based on the data obtained, children often find the difficulties when they studied islamic education. Most of the children (kindergarten and elementary school-age) with parents as Indonesian migrant workers studied in Islamic Kindergarten or Raudhatul Athfal and Islamic Elementary School or Madrasah Ibtidaiyyah. Parents do like to ask their children to study in islamic schools. Because their position who are so far from the children, they believe in islamic schools to get knowledge and also education. They believe that at islamic schools, the teachers are not just teach, but also educate the children. So, the children will not just get the knowledge or quotience, but they also get the moral or character education. It means that the parents' orientation is akhlaq or moral. They do not just study at school, but also join in Taman Pendidikan Qur'an (TPQ) or Qur'an Education Program and also some islamic courses. For courses, there are just little of them who join. Most of them join ngaji or studying islam like studying to read Qur'an after maghrib in the mosque.

Although they have studied at schools and joined some programs, the children often find the difficulties. This difficulties are very felt by the children if both mother and father work abroad. They usually live with grandparents whose low level education, so they cannot get help or more knowledge from their grandparents. Moreover, at home, they also often do not obey the grandparents or mother because there is no father/mother or both of them who 
give good example, especially in practicing every attitude. For example, they postpone to pray because there is no family member who ask or give example to pray on time.

The next one is related to the parents' influence to children's islamic education. There is just little parents' influence to children's islamic education. It is just such kind of order, suggestion and advice. For example, if the position of parents are in other countries to work, they just call the children and just be able to give order, suggestion and advice without any further treatment. Psychologically, they do not do the instruction maximally because the parents cannot monitor them directly. In this condition, grandparents become so hard to face the children.

\section{H. Conclusion}

From this research, there were three answers gotten based on the statements of the problem. The first is, based on the data, it can be concluded that problems faced by the children with parents as immigrant in getting Islamic education are that they do not have the real model in the family and there was no father/ mother or both of them who teach and educate in the family. The second, there is just little parents' influence to children's islamic education. It is just such kind of order, suggestion and advice. And the third is that for getting the islamic education, the children with parents as immigrant workers join several islamic programs. They are Taman Pendidikan Qur'an (TPQ) or Program of Qur'an Education, Madrasah Ibtidaiyyah or Islamic Elementary School, and the islamic courses. 


\section{REFERENCES}

Almerico, Gina M. 2014. Building character through literacy with children's literature. Research in Higher Education Journal Volume 26 - October, 2014. Available at http://www.aabri. com/manuscripts/141989.pdf. Accessed on May 29th 2016.

Bajunid, Omar Farouk. 2011. Islamic Education in Mainland Southeast ASIA: the Dilemmas of Muslim Minorities. Islamic Studies and Islamic Education in Contemporary Southeast Asia. Yayasan Ilmuwan: Kuala Lumpur.

BNP2TKI. 2016. Data of TKI (Indonesian Immigrant Workers) 2016. Available online at http://www.bnp2tki.go.id/ $\mathrm{read} / 11377 /$ Data-Penempatan-dan-Perlindungan-TenagaKerja-Indonesia-Periode-1-JANUARI-S.D-31-MEI-2016. html. Accessed on May 29th 2016.

Denzin, Norman K. and Lincoln, Yvonne S. 2000. Handbook of Qualitative Research (2nd Edition). London: Sage.

Daun, Holger, Arjmand, Reza and Walford, Geoffrey. 2004. "Muslims and Education in a Global Context", in Daun,Holger \& Walford, Geoffrey, eds., Educational Strategies Among Muslims In The Context Of Globalization: Some National Case Studies, Leiden, The Netherlands: Brill NV.

Daun, Holger and Walford, Geoffrey. 2004. Educational Strategies Among Muslims in the Context of Globalization: Some National Case Studies, Leiden, The Netherlands: Brill NV.

Hansen, W.B.; Giles, S.M.; and Fearnow-Kenney, M.D. 2000. Improving Prevention Effectiveness. Greensboro, NC: Tanglewood Research.

John, Kang. 2016. Study Reveals 95\% Of Filipino, Indonesian Helpers In Hong Kong Exploited Or Forced Labor. Forbes, Ed. Mar 18th, 2016. Available online at http://www.forbes. com/sites/johnkang/2016/03/18/study-reveals-95-of- 
filipino-indonesian-helpers-in-hong-kong-exploited-orforced-labor/\#4e0b5fe6149c.

Khoirudin, Danang. 2015. The Influence of Parents (Migrant Workers) to the Moral of Students Class XI SMA Negeri Jumapolo Kabupaten Karanganyar Tahun Pelajaran 2014/2015. Skripsi. UMS.

Prihatini, Danastri. 2013. Psychosocial Problem of Teenagers with Parents as Migrant Workers. Skripsi. UMS.

Salleh, Muhammad Syukri. 2013. Strategizing Islamic Education. International Journal of Education and Research. Available at http://www.ijern.com/journal/June-2013/13.pdf. Accessed on May 29th 2016.

Pokro, Pahlawan. 2002. Optimalyzing the Role of Parents in Developing the Moral of Students in Madrasah Aliyah Negeri Kupang in the Academic Year 2002/2003. Skripsi. UMS. 